\title{
THE CONTENT OF PHENOLIC COMPOUNDS IN UNDERGROUND AND AERIAL PARTS OF DIFFERENT MENTHA SPECIES
}

\author{
Fialová, S. - Tekel'ová, D. - Grančai, D.
}

Comenius University in Bratislava, Faculty of Pharmacy, Department of Pharmacognosy and Botany

\begin{abstract}
Mentha L., the genus belonging to family Lamiaceae, subfamily Nepetoidae, has high commercial importance in the pharmacy as well as in food industry. Mints are available in all five continents and are important sources of each traditional medicine in the prevention and therapy of plenty of diseases. The most active compounds are essential oil and polyphenols. In the past the secondary metabolites in aerial parts were examined, but there is no evidence about the determination of secondary metabolites in underground parts of mints. Therefore the object of this work was to determine the content of phenolic compounds (total hydroxycinnamic derivatives (THD) and flavonoids) of methanol extracts of rhizomes of different Mentha L. and their comparison with leaves extracts. The contents of secondary metabolites were determined using spectrophotometric methods of Slovak Pharmacopoeia. We have detected similar quantities of THD in leaves $(0.79-2.48 \%)$ and rhizomes $(0.96-2.18 \%)$, but underground parts were poor in content of flavonoids $(<0.1 \%)$. The free radical scavenging activity using DPPH free radical was investigated as well. A bit stronger antioxidant activity was shown in leaves extracts considering flavonoids content.
\end{abstract}

Keywords: Mentha - Rhizomes - flavonoids - THD - scavenging activity (DPPH)

\section{INTRODUCTION}

Mints (Mentha L., Lamiaceae) are known and classified as aromatic plants with high content of essential oil and are famous medicinal plants in traditional and conventional medicine all over the world. The genus Mentha includes 18 species and about 11 named hybrids, placed in four sections (Pulegium, Tubulosae, Eriodontes, Mentha). The most used and cultivated mints in the middle Europe are Mentha $\times$ piperita (peppermint) and Mentha spicata (spearmint). In the nature of Slovakia, different species of mints can be found, the most common being M. longifolia, M. verticillata, M. Aquatica, etc. (ŠarićKundalić et al., 2009). The main active component is essential oil, presented by monoterpenes and sesquiterpenes, which varies from species to species (Hayes et al., 2007). The main phenolic compounds in mint are phenolic acids (especially rosmarinic 
acid) and flavonoids (eriodictyol, luteolin, apigenin and their glycosides) (Guédon \& Pasquier, 1994).

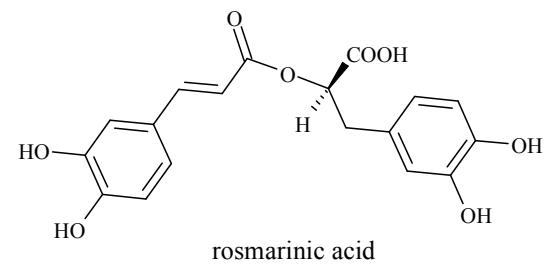<smiles>O=c1cc(-c2ccc(O)c(O)c2)oc2cc(OC3CC(O)C(O)C(CO)O3)cc(O)c12</smiles>

Several authors have reviewed the literature with respect to the medicinal uses of peppermint. Peppermint has been reported to possess these biological activities: digestive, cholekinetic, choleretic, antispasmodic, antibacterial, antiviral, fungicidal, antioxidant, anti-inflammatory, expectorant, myorelaxant, analgesic as well as insecticidal, aphrodisiac, local anaesthetic, antiemetic, antiulcer, astringent, vasodilatator, etc. (Duke, 2002), (Mckay \& Blumberg, 2006). An infusion of dried peppermint leaves was noted to be useful in the treatment of intestinal spasms of the alimentary canal, atony of stomach, flatulence (Flück \& Jaspersen-Schib, 1976). Many of these effects depend on phenolic compounds, thanks to its antioxidant activity. For the medicinal purposes usually used leaves or the whole aerial part is used. Most species of the genus Mentha produce long, thin rhizomes, which are not known to use for medicinal or other purpose. This study was based on questions: What secondary metabolites could be found in rhizomes? Could extracts of rhizomes have any fpharmacological activity? Could they be advised for medicinal purposes? The current available literature on the genus Mentha L. does not provide any information about contents of secondary metabolites in underground parts. Therefore, in our study we have investigated the presence and the contents of phenol compounds in underground parts of different mints and we have compared the results obtained from rhizomes with the results from leaves.

\section{MATERIAL AND METHODS}

\section{Plant material}

All mints $[M . \times$ piperita cv. 'Perpeta' (MP), M. spicata ssp. spicata (MS), M. spicata var. crispa $(\mathrm{MSC}), M . \times$ villosa $(\mathrm{MV}), M . \times$ villosa cv. 'Snežná' (MVS), M. longifolia ssp. longifolia (ML), M. longifolia var. lavanduliodora (MLL)] used in this study were cultivated in the climatic conditions of south-west Slovakia, in the Garden of Medicinal Plants, Faculty of Pharmacy in Bratislava. Cultures were planted on a light sand-loam soil in a sunny location. The leaves were harvested in July 2009, during plant flowering and rhizomes in November 2009. The plants were dried at 32 - $35{ }^{\circ} \mathrm{C}$. Voucher specimens were deposited at the Department of Pharmacognosy and Botany, Faculty of Pharmacy, Comenius University, Bratislava.

Methods 
Extract: methanol extracts were prepared using $2.00 \mathrm{~g}$ of powdered dry leaves or rhizomes and $20 \mathrm{~g}(2 \times 10 \mathrm{~g})$ of solvent. The extraction was provided by sonication $2 \mathrm{x}$ $30 \mathrm{~min}$. The solvent was evaporated after extraction; extract was weighted and again dissolved in methanol for the analyses.

1) The determination of secondary metabolites

Phenol compounds were determined using spectrophotometric methods of the Slovak Pharmacopoeia first edition (Ph.S. I, 2001).

Total hydroxycinnamic derivatives (THD, Arnow's assay)

The content of THD was determined using a colorimetric method with the Arnow's reagent at $505 \mathrm{~nm}$ (Spectrophotometer Thermo, Electron Corporation Genesys 6, United Kingdom). The percentage contents of THD were calculated and expressed as rosmarinic acid.

Flavonoids (Spectrophotometric assay)

The content of total flavonoids was determined by a spectrophotometric method using aluminium chloride at $392 \mathrm{~nm}$ (Spectrophotometer Thermo, Electron Corporation Genesys 6, United Kingdom). The percentage contents were calculated and expressed as luteolin-7-O-glucoside.

2) The determination of free radical scavenging activity

DPPH test

The free radical scavenging activity of methanol extracts was estimated using the $\mathrm{DPPH}$, colour-free radical solution $(55 \mu \mathrm{mol} / \mathrm{l})$. The activity was expressed as $\mathrm{SC}_{50}$ $\left(\mu \mathrm{g} \cdot \mathrm{ml}^{-1}\right)$, which is the concentration of the test solution required to give a $50 \%$ decrease in absorbance from that of a blank solution (Lamaison et al., 1990, 1991), (Nagy et al., 2006). Trolox, ascorbic acid and rosmarinic acid were used as a positive control.

All analyses were made in triplicate. The percentage content of investigated phenolic compounds was calculated with reference to the dry drug weight.

\section{RESULTS}

As described above the extraction was performed by sonication using methanol as solvent. After extraction, the solvent was evaporated to obtain dry extract. The amounts of dry extracts are presented in Table 1. The extraction yields from rhizomes were about half of extraction yields from leaves. The best yield of dry extract from leaves was detected in $M$. piperita $(22.6 \%)$, while the highest yield from rhizomes was found in M. longifolia var. lavanduliodora (12.1\%). 
Table 1. The yield of extraction using methanol in \%

\begin{tabular}{|c|c|c|}
\hline Mentha L. & $\begin{array}{ll} & \text { Yie } \\
\text { leaves } & \end{array}$ & $\begin{array}{l}\text { raction }[\% \\
\text { rhizomes }\end{array}$ \\
\hline MP & 22.6 & 11.8 \\
\hline MS & 21.6 & 11.4 \\
\hline MSC & 14.4 & 7.6 \\
\hline MV & 19.1 & 11.9 \\
\hline MVS & 14.9 & 10.1 \\
\hline ML & 17.2 & 7.6 \\
\hline MLL & 16.3 & 12.1 \\
\hline
\end{tabular}

For the determinations of total hydroxycinnamic derivatives expressed as rosmarinic acid and flavonoids expressed as luteolin-7-O-glucoside were performed using spectrophotometrical methods from Slovak Pharmacopoeia $1^{\text {st }}$ edition. The results are found in Table 2. The highest content of THD as well as flavonoids was detected in leaves extracts of $M$. piperita $(2.48 \%$ and $1.08 \%$ resp.).

Table 2. The percentage contents of THD and flavonoids in leaves and rhizomes of different Mentha sp.

\begin{tabular}{|c|c|c|c|c|}
\hline \multirow[t]{2}{*}{$\begin{array}{l}\text { Mentha } \\
\text { L. }\end{array}$} & \multicolumn{2}{|c|}{$\begin{array}{l}\text { The content } * \text { of THD expressed } \\
\text { as } \\
\text { Rosmarinic acid }(\lambda=505 \mathrm{~nm}) \\
{[\%] \pm \text { SD }}\end{array}$} & \multicolumn{2}{|c|}{$\begin{array}{l}\text { The content* of flavonoids } \\
\text { expressed as } \\
\text { luteolin-7- } O \text {-glucoside }(\lambda=392 \\
\text { nm) } \\
{[\%] \pm \text { SD }}\end{array}$} \\
\hline & leaves & rhizomes & leaves & Rhizomes \\
\hline MP & $\mathbf{2 . 4 8} \pm 0,30$ & $1.14 \pm 0.05$ & $\mathbf{1 . 0 8} \pm 0.11$ & $<0.01$ \\
\hline MS & $1.95 \pm 0.07$ & $\mathbf{2 . 1 8} \pm 0.01$ & $0.14 \pm 0.01$ & $<0.01$ \\
\hline MSC & $1.15 \pm 0.11$ & $0.96 \pm 0.08$ & $0.14 \pm 0.01$ & $<0.01$ \\
\hline MV & $1.32 \pm 0.17$ & $1.01 \pm 0.29$ & $0.60 \pm 0.05$ & $<0.01$ \\
\hline MVS & $1.55 \pm 0.15$ & $1.01 \pm 0.35$ & $0.98 \pm 0.06$ & $<0.01$ \\
\hline ML & $1.67 \pm 0.12$ & $1.98 \pm 0.57$ & $0.63 \pm 0.06$ & $<0.01$ \\
\hline MLL & $0.79 \pm 0.02$ & $1.31 \pm 0.41$ & $0.27 \pm 0.02$ & $<0.01$ \\
\hline
\end{tabular}

* in dry drug; MP - M. × piperita cv. 'Perpeta', MS - M. spicata ssp. spicata, MSC - M. spicata var. crispa, MV-M. × villosa, MVS - M. × villosa cv. 'Snežná', ML - M. longifolia ssp. longifolia, MLL M. longifolia var. lavanduliodora

The antioxidant activity was expressed as concentration of extract scavenging $50 \%$ of DPPH free radical (Table. 3, Figure. 1). The highest activity was detected in leaves 
of $M$. piperita. The scavenging activity was stronger in leaves extract of each investigated mint except $M$. longifolia var. lavanduliodora.

Table 3. The comparison of DPPH scavenging activity of dry methanol extracts of leaves and rhizomes in different Mentha sp.

\begin{tabular}{lcc} 
& \multicolumn{2}{c}{ AA SC $_{\mathbf{5 0}}[\boldsymbol{\mu g} / \mathrm{ml}] *$ SD } \\
Mentha L. & leaves & Rhizomes \\
\hline MP & $\mathbf{8 . 2 4} \pm 1.03$ & $18.1 \pm 1.86$ \\
MS & $9.28 \pm 0.45$ & $\mathbf{1 0 . 5} \pm 0.20$ \\
MSC & $13.62 \pm 1.28$ & $14.3 \pm 0.20$ \\
MV & $10.17 \pm 0.13$ & $13.2 \pm 0.17$ \\
MVS & $10.50 \pm 1.17$ & $20.5 \pm 0.32$ \\
ML & $9.55 \pm 0.12$ & $14.1 \pm 0.15$ \\
MLL & $5.83 \pm 0.65$ & $12.6 \pm 0.08$ \\
Trolox ${ }^{\text {a }}$ & & $6.20 \pm 0.06$ \\
Rosmarinic acid & & $1.72 \pm 0.13$ \\
Ascorbic acid & & $1.69 \pm 0.03$
\end{tabular}

* dry methanol extract; MP - M. × piperita cv. 'Perpeta', MS - M. spicata ssp. spicata, MSC - M. spicata var. crispa, MV-M. $\times$ villosa, MVS - M. $\times$ villosa cv. 'Snežná', ML - M. longifolia ssp.

longifolia, MLL - M. longifolia var. lavanduliodora

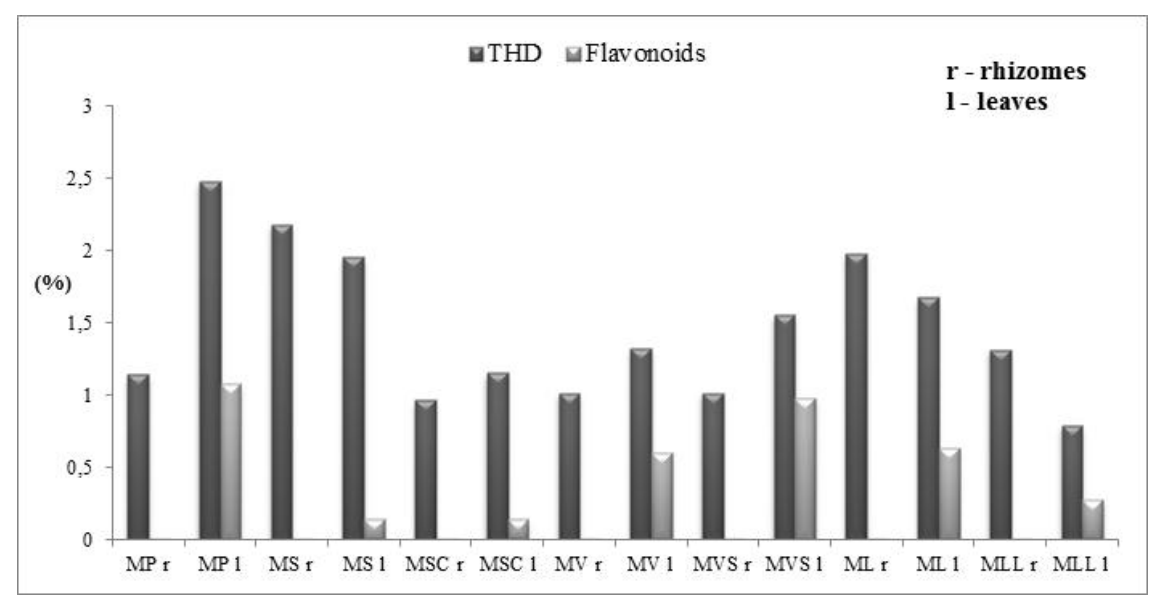

Figure. 1 The comparison of THD and flavonoids contents in rhizomes (r) and leaves (I) in different Mentha L. (MP -M. × piperita cv. 'Perpeta', MS - M. spicata ssp. spicata, MSC - M. spicata var. crispa, MV-M. $\times$ villosa, MVS - M. $\times$ villosa $\mathrm{cv}$. 'Snežná', ML - M. longifolia ssp. longifolia, MLL - M. longifolia var. lavanduliodora) 


\section{DISCUSSION}

The organism disposes own enzymatic mechanisms that eliminate free radicals in the body. Important roles in this process are played by substances with antioxidant effects presented in daily food. Those participate on elimination of pathological free radicals formation. The balance between antioxidant and prooxidant pathways is most appropriate. Long-term precarious balance inclined to the side of the prooxidative processes can be described as redox stress (Rice-Evans et al., 1996). Oxidation stress affects all tissues and all types of macromolecules in the cell (DNA, proteins, carbohydrates, lipids) (Duračková, 1998). In recent times, there has been wide research on natural antioxidants, key components in the protection mechanism against free radicals. The group of natural antioxidants is quite broad and includes mainly polyphenols (flavonoids, catechins, phenolic acids and their derivatives). Polyphenol compounds are also present in the species of the genus Mentha. The aerial parts of mints present an easily available source of natural antioxidants for medicine and pharmacy (Kähkönen et al., 1999), (Dorman et al., 2009).

It is known that mints produce a huge net of underground rhizomes and this net enlarges from year to year because of perennial character of these plants. For commercial purposes the yield of aerial part is important, since it is used in pharmacy, cosmetics and culinary, and especially because of essential oil present in leaves. But mints of course contain other active secondary metabolites which are responsible for many pharmacological effects.

This study was aimed to evaluate the contents of main secondary metabolites in leaves and rhizomes of seven mints. There are no indications in available literature about chemical composition or antioxidant activity in rhizomes of mints. In connection to Lamiaceae family, there were investigated rhizomes of some other species i.e. three antioxidant phenylethanoid glycosides were found in rhizomes of Eremostachys pulvinaris (forsythoside B, leucosceptoside A and verbascoside) (Delazar et al., 2004). The analysed extracts of leaves and rhizomes were prepared by sonication. For the extraction of phenol secondary metabolites we used methanol. The suitability of methanol as a solvent was recommended for these purposes in the available literature (Dorman et al., 2009), (Areias et al., 2001). The percentage content of THD in leaves' extracts varied from $0.79 \%$ to $2.48 \%$ and of flavonoids from $0.14 \%$ to $1.08 \%$. We have detected that the presence of THD in rhizomes as well and their contents in rhizomes were approximately equa $1(0.96-2.18 \%)$ to their contents in leaves, in some cases higher. Also flavonoids were investigated in rhizome extracts using spectrophotometric method and expressed as luteolin-7-O-glucoside; because luteolin derivatives have major position of all flavonoids in mints (Fialová et al., 2009). In comparison to leaves we found only trace content of flavonoids in underground parts.

While studying extracts we also examined DPPH radical scavenging activity, the results of which can be found in table 3. We suppose that flavonoid's absence reflects in lower free DPPH radical scavenging activity of rhizomes extracts. This is particularly visible in peppermint (MP), horse mint (ML), and apple mint (MV), whose leaves are rich in flavonoids. The antioxidant activity of leaves and rhizomes of mints seems to be associated chiefly with the content of hydroxycinnamic derivatives. High scavenging activity of methanol extract of spearmint (M1) rhizomes compared to other mints could 
be caused by a high content of rosmarinic acid, which has been previously detected in leaves of this species (Fialová, 2010). Anyway stronger scavenging activity of leaves extracts is supported by flavonoids content. Scavenging activity in rhizomes extracts do not correlate with the content of THD, therefore we have to consider other antioxidant substances within extracts or their synergic effect.

According to previous scientific research and our knowledge about mints, we are not awaiting any toxicity in rhizomes in spite of not investigating the presence of essential oil components or other compounds in rhizomes. The results of our study should be the reason for rhizomes usage in therapy, or prevention of some disease as in aerial parts mentioned above.

\section{CONCLUSION}

This study gives information about phenolic compounds and antioxidant effect of methanol extract of rhizomes in comparison to leaves of different mints. The contents of total hydroxycinnamic derivatives were almost equal in rhizomes and leaves, contrary to total flavonoids expressed as luteolin-7-O-glucoside contents which were higher in leaves. Methanol extracts of rhizomes exhibit quite strong DPPH radical scavenging activity, but lower than that in leaves, probably because of low presence of flavonoids.

\section{ACKNOWLEDGMENTS}

This work was supported by VEGA grant 1/0059/11 and FaF UK/10/2012.

\section{REFERENCES}

Areias FM, Valentao P, Andrade PB, Ferreres F, Seabra RM. Phenolic fingerprint of peppermint leaves. Food Chem. 2001;73:307-311.

Delazar A, Sarker SD, Shoeb M, Kumarasamy Y, Nahar L, Nazemyieh H. Three antioxidant phenylethanoid glycosides from the rhizomes of Eremostachys pulvinaris (family: Labiatae): J Pharm Res. 2004;3 (2):23-24.

Dorman DJH, Kosar M, Kahlos K, Holm Y, Hiltunen K. Phenolic Profile and antioxidant evaluation of Mentha $\mathrm{x}$ pipretia L. (peppermint) extracts. Nat Prod Commun. 2009;4:535-542.

Duke JA. Handbook of medicinal herbs 2nd ed. CRC Press Boca Raton, 2002.

Ďuračková Z. Vol’né radikály a antioxidanty v medicíne I. Slovak Academic Press Bratislava.1998. 
Fialová S, Prinz S, Zehl M, Tekel'ová D, Reznicek G, Grančai D, Kopp B. Polyphenolic fingerprint of methanolic extracts of Mentha sp. cultivated in Slovakia. Planta Med. 2009;75:889.

Fialová S. Farmakognostický prieskum vybraných liečivých rastlín (rod Mentha L.): dizertačná práca, Bratislava: Univerzita Komenského, 2010.

Flück R, Jaspersen-Schib R. Medicinal plants and their uses. W. Foulsham \& Co. Ltd., London, UK 1976.

Guédon DJ, Pasquier BP. Analysis and distribution of flavonoid glycosides and rosmarinic acid in 40 Mentha $\times$ piperita clones. J Agric Food Chem 1994;42:679-684.

Hayes JR, Stavanja MS, Lawrence BM. Mint: The genus Mentha. CRC Press, Taylor \& Francis Group, Boca Raton; 2007.

Kähkönen MP, Hopia AI, Vuorela HJ, Rauha JP, Pihlaja K, Kujala TS, Heinonen M. Antioxidant activity of plant extracts containing phenolic compounds. J Agric Food Chem. 1999; 47:3954-3962.

Lamaison JL, Petitjean-Freytet C, Carnat A. Lamiacées médicinales á propriétés antioxydantes, sources potentielles d'acide rosmarinique. Pharm Acta Helv. 1991;66:185-188.

Lamaison JL, Petitjean-Freytet C, Carnat A. Teneurs en rosmarinique, en dérivés hydroxycinnamiques totaux et activité antioxydante chez les Apiacées, les Boraginacées et les Lamiacées médicinales. Ann Pharm Fr. 1990;48:103-108.

Mckay DL, Blumberg JB. A review of the bioactivity and potential health benefits of peppermint tea (Mentha piperita L.). Phytother Res. 2006;20:619-633.

Nagy M, Spilková J, Vrchovská V, Kontšeková Z, Šeršeň F, Mučaji P, Grančai D. Free radical scavenging activity of different extracts and some constituents from the leaves of Ligustrum vulgare and L. delavayanum. Fitoterapia. 2006;77:395-397.

Rice-Evans CA, Miller NJ, Paganga G. Structure-antioxidant activity relationships of flavonoids and phenolic acids. Free Radic Biol Med. 1996;20(7):933-956.

Slovak Pharmacopoeia $1^{\text {st }}$ edition. Bratislava. Herba, 2001-2003.

Šarić-Kundalić B, Fialová S, Dobeš CH, Ölzant S, Tekel'ová D, Grančai D, Reznicek G, Saukel J. Multivariete numerical taxonomy of Mentha species, hybrids, varieties and cultivars: Sci Pharm. 2009;77:851-876. 


\title{
OBSAH FENOLOVÝCH LÁTOK V NADZEMNÝCH A PODZEMNÝCH ČASTIACH RÔZNYCH DRUHOV RODU MENTHA
}

\author{
Fialová, S. - Tekel'ová, D. - Grančai, D.
}

Univerzita Komenského v Bratislave, Farmacutická fakulta, Katedra farmakognózie a botaniky

Rod Mentha L. z čel'ade Lamiaceae, podčel'ade Nepetoidae, má vysoký komerčný význam vo farmácii, ako aj v potravinárskom priemysle. Mäty sa nachádzajú na všetkých piatich kontinentoch a sú dôležitým súčast'ou každej tradičnej medicíny v prevencii a pri liečenie rôznych ochorení. Účinnými zložkami sú silica a fenolové látky. V minulosti boli sekundárne metabolity skúmané najmä v nadzemných častiach, avšak neuvádza sa stanovenie sekundárnych metabolitov v podzemných častiach mäty. Predmetom tejto práce bolo preto stanovenie obsahu fenolových látok (celkové hydroxyškoricové deriváty (THD) a flavonoidy) v metanolových extraktoch podzemkov rôznych druhov rodu Mentha L. a ich porovnanie s extraktmi z listov. Obsah sekundárnych metabolitov sa stanovil použitím spektrofotometrických metód Slovenského liekopisu. Zistili sme približne rovnaký obsah THD v listoch $(0,79-2,48 \%)$ a podzemkoch $(0,96$ - 2,18 \%), avšak podzemné časti neobsahovali takmer žiadne flavonoidy $(<0,1 \%)$. Súčastou práce bolo aj stanovenie antioxidačnej aktivity použitím DPPH vol’ného radikálu. Silnejšia antioxidačná aktivita sa zaznamenala $\mathrm{v}$ extraktoch $\mathrm{z}$ listov, pravdepodobne vd’aka vyššiemu obsahu flavonoidov.

Acta Fac. Pharm. Univ. Comen. LIX, 2012, p. 30-38. 